\title{
THE FALLACY OF PERSONAL VALIDATION (THE FORER EFFECT) IN THE SYSTEM OF BEHAVIORAL FINANCE BIASES
}

Hayrapetyan D. R. (Yerevan State University, Yerevan, Armenia) davidhaiarm@ysu.am

Utinluјшgúuи uर्u. 27.12.2021

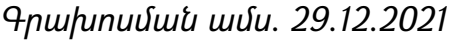

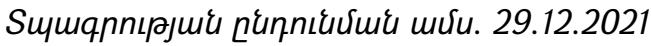

The main purpose of the research paper is to understand the interrelation of the fallacy of personal validation also called The Forer effect or The Barnum effect with one of the main biases of behavioral finances the money illusion. During the last years we explored some personal factors which force and determinate the manifestation of money behavior such as subjective control, aspiration level etc. All of data force us to suppose that one of regulators of money behaviour is the belief in authority and obedience to expert opinion which could be measured by the level of manifestation of the fallacy of personal validation. This means that people are gullible because they think the information is about them only when in fact the information is generic. The research design is aimed to study and understand the manifestation of the money illusion among the people affected by the fallacy of personal validation (The Forer effect). This can help us to understand more deeply the phenomena of money illusion which nowadays affect more extensively our financial behaviour.

Keywords: fallacy of personal validation, the Forer effect, money illusion, behavioral finance biases.

DOI: https://doi.org/10.46991/SBMP/2022.5.1.056

\section{Theoretical background.}

One of the main biases of behavioral finances - Money Illusion (later MI) we are studying since 2011 and there is more than 10 article where we try to understand the manifestation of $\mathrm{Ml}$ in different situations and ways of its overcoming $[6,7,8]$.

Ml describes the tendency of people to take the nominal value of money, not its real purchasing power [9]. The term was introduced by Irving Fisher and he gave his economic definition. Fisher first began to discuss the problem of inconsistency of variability of money purchasing power and its constant perception. As he aptly remarked: in our perception "the dollar is the dollar" and "franc is the franc," although in 1913 by 70 cents we could buy as many goods as by 100 cents in 1928. And it is correct to assert that the dollar costs about 70 
cents or its purchasing power is such. Despite, the public doesn't know that such problem exists and the study of this phenomenon is only within a narrow range of scientific discussions [2].

In our previous researches we tried to establish the effect of the use of computational tools (the calculator) to change the level of MI. The results allowed concluding that MI, after the use of the computational tool, did not change and it is a more stable phenomenon. Afterwards, we tried to find the other regulators of $\mathrm{Ml}$ and put forward another hypothesis: the changes of $\mathrm{Ml}$ may occur in communication, more specifically, discussion in pairs. The results show a statistically significant difference between the $\mathrm{Ml}$ individual and $\mathrm{Ml}$ communication [6]. This allows us to state that the Ml does not depend on a human motivation such peculiarity, as to be consumer of good or only it's customer. MI manifests itself as a more persistent phenomenon and observed equally to both consumer and customer. But taking into consideration the phenomenon that customers are prone to excess costs, it makes us to design new methods of diagnosis of Ml, which will take over the costs of customers that can radically change the picture of customer's behavior. The latest can be the reason for new researches [7]. In latest researches we found that if the currency has a higher rate, it is perceived and evaluated more valuable, independent, heavy, strong and the willingness to overpay in that currency is higher [8].

These conclusions allow us to suppose that the level of $\mathrm{Ml}$ as a bias can be in correlation with the fallacy of personal validation. The Forer Effect (also called Barnum effect, later FE) takes its name from Psychologist Bertram Forer who conducted a canonical experiment in 1948 in which he asked some of his students to "reveal' their personalities by filling in missing words in a series of phrases. A week later each student was given an individualized personality sketch 'tailored to their results', which in reality were identical descriptions, and asked to rate their accuracy. Forer's descriptions received an average accuracy rating of 4.26 out of 5 , an $84 \%$ degree of accuracy [2].

There are some general causes that assure the manifestation of the fallacy of personal validation.

1. Preference for Likeability. We are predisposed to believe in positive statements about ourselves.

2. Preference for Relatability. We are naturally prone to take information that we can relate to ourselves and connect it to our daily-life occurrences.

3. Pollyanna Principle. It's ours tendency to remember pleasant events more accurately than negative ones [4].

There is some personal and psychological particularities in the FE manifestation that are discovered in different studies. The effect may be influenced both by motivational factors and by cognitive factors related to our 
failure to adjust for the lesser availability of confirming evidence regarding the little-known other. Because both the amount of available information and the desire to view an individual positively may increase with degree of acquaintance, cognitive and motivational influences may converge for positive descriptions, producing a systematic positive relation between familiarity and judged accuracy. With negative descriptions, however, cognitive and motivational influences may produce opposing tendencies [5].

All these researches and results push us to organize our research to understand the interrelation of two fallacies - MI and FE.

\section{Study 1}

Method: We have chosen a personality test composed by 30 questions and provided it to the students of different profession $(n=98)$. In the main instruction it was mentioned that test is very popular in the world and gives reliable results. After collecting the answer's blanks we transferred it to an assistant to analyze results. After that we measured Ml coefficient [6] and while they finish work we presented the same answer to all of people in their name on blank and asked to measure the relevance in the scale of 10 points. The answer was taken from Forer experiment. "You have a great need for other people to like and admire you. You have a tendency to be critical of yourself. You have a great deal of unused capacity which you have not turned to your advantage. While you have some personality weaknesses, you are generally able to compensate for them. Your sexual adjustment has presented problems for you. Disciplined and selfcontrolled outside, you tend to be worrisome and insecure inside. At times you have serious doubts as to whether you have made the right decision or done the right thing. You prefer a certain amount of change and variety and become dissatisfied when hemmed in by restrictions and limitations. You pride yourself as an independent thinker and do not accept others' statements without satisfactory proof. You have found it unwise to be too frank in revealing yourself to others. At times you are extroverted, affable, sociable, while at other times you are introverted, wary, reserved. Some of your aspirations tend to be pretty unrealistic. Security is one of your major goals in life."

Results and discussion

In experimental group we the mean accuracy rating was 7.9 (one simple TTest $\mathrm{p}=.000$ ), which allow us assume statistically significant manifestation of personal validation in experimental group. The coefficient of $\mathrm{Ml}$ was 1.21 (one simple T-Test $\mathrm{p}=.000$ ), which prove also the statistically significant MI. One simple K-S test show the distribution of results is different of normal $p=.000$ for FE and $p=.003$ for MI. Negative skewness in scale FE is noticed.

Correlation analysis didn't show any correlation between FE and MI (Spearman's rho $\mathrm{p}=.902$ ). 
According to the results we can assume that in the experimental group we can notice the manifestation both of fallacies FE and MI, but these two phenomena didn't related. To understand the nature of manifestation of both we organized another study.

\section{Study 2}

Method: All the procedures are the same as in Study 1 except in the main instruction it was mentioned that the test is in the testing phase and your honest work will help us improve the reliability of the test. We tried to eliminate the influence of authority to the manifestation of FE.

Results and discussion: In this group we the mean accuracy rating was 8.4 (one simple T-Test $\mathrm{p}=.000$ ), which allow us assume statistically significant manifestation of personal validation in this group also. The coefficient of Ml was 1.12 (one simple T-Test $\mathrm{p}=.000$ ), which prove also the statistically significant MI. One simple K-S test show the distribution of results is different of normal for $\mathrm{FE}$ $\mathrm{p}=.000$ but normal for $\mathrm{Ml} \mathrm{p}=.189$. Negative skewness in scale FE is noticed.

In this group we assure positive correlation between FE and MI (Spearman's rho $\mathrm{p}=.045)$. So in this group we can conclude that the increasing of level if $\mathrm{Ml}$ is correlated by the increase of personal validation (FE).

General results and discussion: In whole group $(n=163)$ the mean accuracy rating was 8.1 (one simple T-Test $p=.000$ ), which allow us assume statistically significant manifestation of personal validation. The coefficient of $\mathrm{Ml}$ was 1.18 (one simple T-Test $\mathrm{p}=.000$ ), which prove also the statistically significant MI. One simple K-S test show the distribution of results is different of normal $p=.000$ for FE and $\mathrm{p}=.001$ for MI.

If we compare the manifestation of FE in two group we can assume that two group are identic (Levene's $p=.010$, U Mann-Whitney $p=.201$ ). The manifestation of $\mathrm{Ml}$ in two group also is the same (Levene's $\mathrm{p}=.058$, T-test $p=.21$ ). The only difference that distribution in $\mathrm{Ml}$ scale become not normal $(p=.028)$.

Correlation analysis didn't show any correlation between FE and $\mathrm{Ml}$ (Spearman's rho $\mathrm{p}=$.247). So the problem of correlation lose is the distribution of results. To explain this particularity we need more precise analysis.

In the figure 1 we can see the FE rate in 3 main groups of $\mathrm{Ml}$ manifestation (not manifest, normal, high) 


\section{FE}

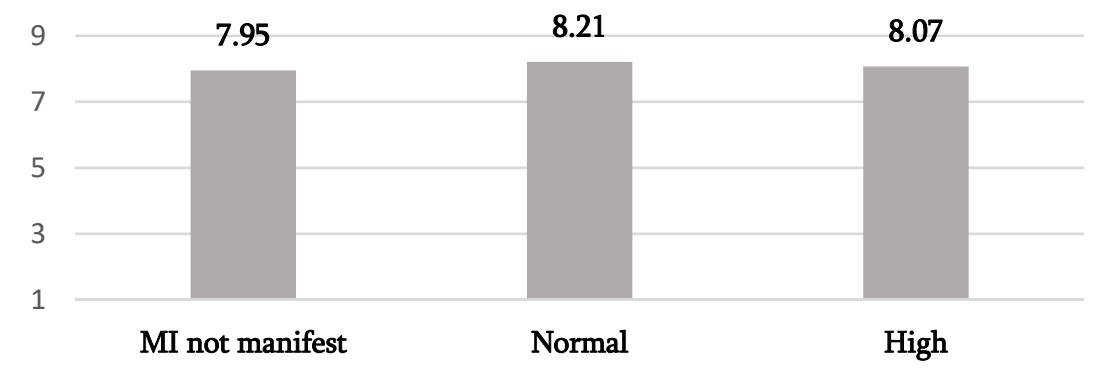

Figure 1. FE rate in 3 main groups of $\mathrm{Ml}$ manifestation

As we can see the FE manifestation increase when Ml is noted. But in experimental group (Study 1) we have some people with very high manifestation of $\mathrm{Ml}$ among which FE decrease. To understand this pattern, we need future studies of these fallacies.

Conclusions

The fallacy of personal validation is very sustainable phenomena and it's manifestation didn't decrease if even we eliminate the authority factor. We can't notice normal distribution of results cause of high manifestation of it. Negative skewness of results is stated.

Cause of negative skewness and we can't state the correlation between FE and Ml. Also it caused by some high manifestation of $\mathrm{Ml}$ in experimental group.

Positive correlation between FE and $\mathrm{Ml}$ is noticed in the study where the authority factor didn't present during FE measurement.

\section{References}

1. Dickson, D.H. and I.W. Kelly. "The 'Barnum Effect' in Personality Assessment: A Review of the Literature," Psychological Reports, 1985, p. 57, pp. 367-382.

2. Fisher,I. The Money Illusion, New york: Adelphi Company 1928, p. 245

3. Forer, B. R. (1949). The fallacy of personal validation: a classroom demonstration of gullibility. The Journal of Abnormal and Social Psychology, 44(1), pp. 118-123.

4. Furnham, A., \& Schofield, S. (1987). Accepting personality test feedback: A review of the Barnum effect. Current Psychological Research \& Reviews, 6(2), pp. 162-178. 
5. Johnson, J. T., Cain, L. M., Falke, T. L., Hayman, J., \& Perillo, E. (1985). The "Barnum effect" revisited: Cognitive and motivational factors in the acceptance of personality descriptions. Journal of Personality and Social Psychology, 49(5), pp. 1378-1391.

6. Hayrapetyan D. (2012) The psychometric parameters of technique of psychodiagnostic of money illusion. Bulletin of Yerevan University, 2012. N 137.4 ,Yerevan, pp. 55-64.

7. Hayrapetyan D. (2014) Consumer versus customer: manifestation of money illusion in the human motivational system. Шестая международная конференция по когнитивной науке: Тезисы докладов: Калининград, 23-27 июня 2014 г. - Калининград, с.58-59.

8. Hayrapetyan D. (2015) Money and currency perception in the financial behavior of economic agent. "Stumlumi u uhnunulumi hnqtipuiunıpuiu

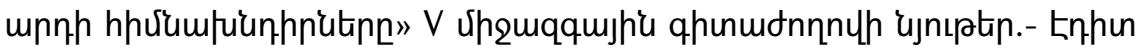
unhiuu hnum., 2013, 52 637-640

9. Shafir E., Diamond P., Tversky A. Money Illusion. The Quarterly Journal of Economics, Vol. 112, No.2 1997, pp. 34I-374.

\section{ОШИБКА ЛИЧНОСТНОГО УТВЕРЖДЕНИЯ (ЭФФЕКТ ФОРЕРА) В СИСТЕМЕ ПРЕДУБЕЖДЕНИЙ ПОВЕДЕНЧЕСКИХ ФИНАНСОВ}

Айрапетян Д. Р. (Ереванский государственный университет, Ереван, Армения)

Основная цель исследовательской работы - понять взаимосвязь ошибки личной проверки, также называемой эфффектом Форера или эфффектом Барнума, с одним из основных предубеждений поведенческих финансов денежной иллюзией. В течение последних лет мы исследовали некоторые личные факторы, которые вызывают и определяют проявление денежной иллюзии, такие как субъективный контроль, уровень стремления и т. д. Все данные заставляют нас предположить, что одним из регуляторов денежного поведения является вера в авторитет и подчинение экспертному мнению, которое может быть измерено уровнем проявления ошибочности личной оценки. Это означает, что люди легковерны, потому что думают, что информация касается их только тогда, когда на самом деле информация носит общий характер. Дизайн исследования направлен на изучение и понимание проявления денежной иллюзии среди людей, подверженных ошибке личной проверки (эффрект Форера). Это может помочь нам глубже понять френомен денежной иллюзии, который в наши дни более широко влияет на наше фринансовое поведение. 
Ключевые слова: ошибка личной проверки, эффект Форера, денежная иллюзия, искажения поведенческих финансов.

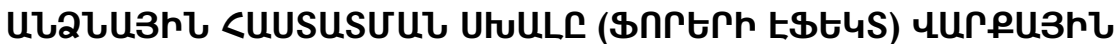

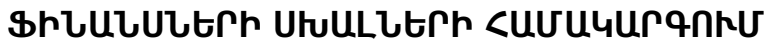

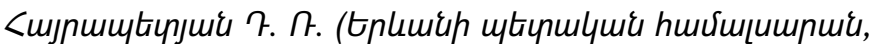

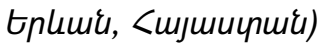

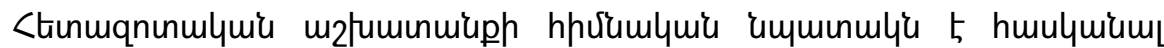

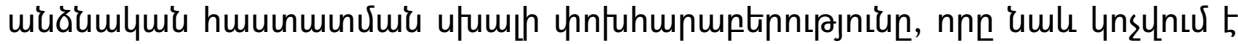

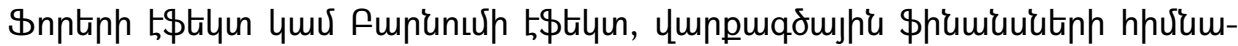

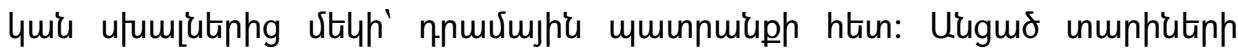

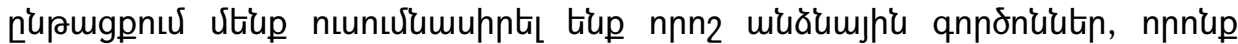

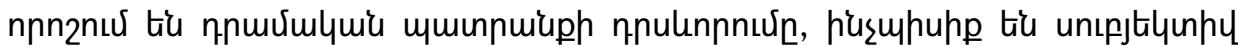

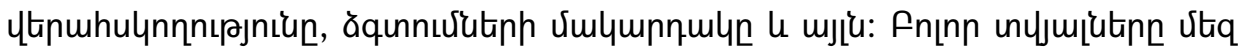

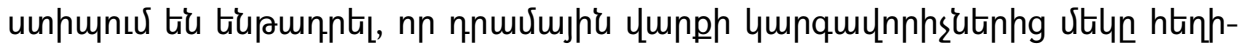

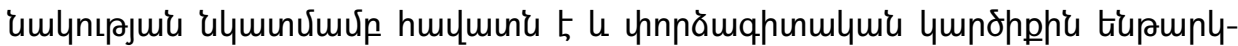

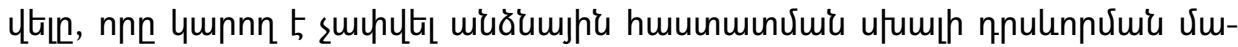

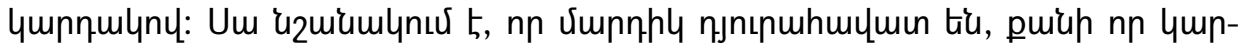

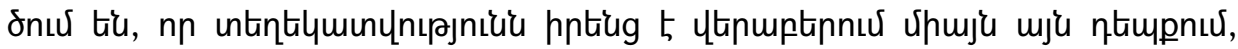

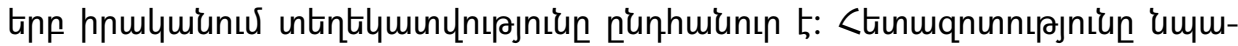

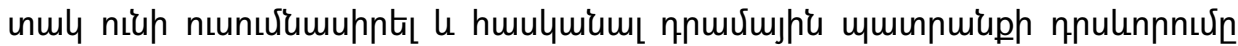

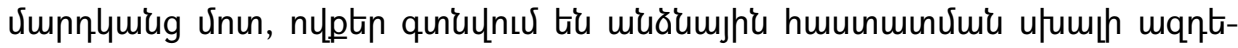

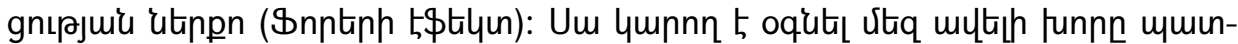

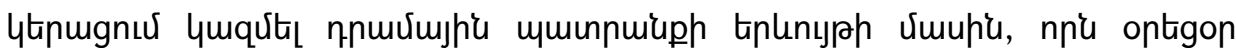

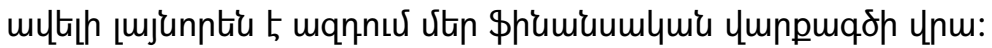

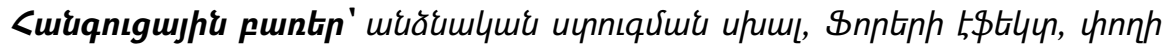

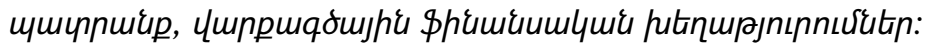

